medRxiv preprint doi: https://doi.org/10.1101/2020.07.18.20155374; this version posted July 20, 2020. The copyright holder for this preprint

(which was not certified by peer review) is the author/funder, who has granted medRxiv a license to display the preprint in perpetuity.

It is made available under a CC-BY 4.0 International license.

\title{
Dynamics and significance of the antibody response to SARS-CoV-2 infection
}

Anita S. Iyer ${ }^{\mathrm{a}, \mathrm{b}^{*}}$, Forrest K. Jones ${ }^{\mathrm{c}^{*}}$, Ariana Nodoushani ${ }^{\mathrm{a}^{*}}$, Meagan Kelly ${ }^{\mathrm{a}}$, Margaret Becker ${ }^{\mathrm{a}}$, Damien Slater ${ }^{\mathrm{a}}$, Rachel Mills ${ }^{\mathrm{a}}$, Erica Teng ${ }^{\mathrm{a}}$, Mohammad Kamruzzamana ${ }^{\mathrm{a}}$, Wilfredo F. GarciaBeltran $^{\mathrm{d}}$, Michael Astudillo ${ }^{\mathrm{d}}$, Diane Yang ${ }^{\mathrm{d}}$, Tyler E. Miller ${ }^{\mathrm{d}}$, Elizabeth Oliver ${ }^{\mathrm{a}}$, Stephanie

Fischinger $^{\mathrm{e}}$, Caroline Atyeo ${ }^{\mathrm{e}}$, A. John Iafrate ${ }^{\mathrm{d}}$, Stephen B. Calderwood ${ }^{\mathrm{a}, \mathrm{b}, \mathrm{f}}$, Stephen A. Lauer ${ }^{\mathrm{c}}$, Jingyou $\mathrm{Yu}^{\mathrm{g}}$, Zhenfeng $\mathrm{Li}^{\mathrm{g}}$, Jared Feldman ${ }^{\mathrm{e}}$, Blake M. Hauser ${ }^{\mathrm{e}}$, Timothy M. Caradonna ${ }^{\mathrm{e}}$, John A. Branda $^{\mathrm{d}}$, Sarah E.Turbett ${ }^{\mathrm{a}, \mathrm{b}, \mathrm{d}}$, Regina C. LaRocque ${ }^{\mathrm{a}, \mathrm{b}}$, Guillaume Mellon ${ }^{\mathrm{a}}$, Dan H. Barouch ${ }^{\mathrm{e}, \mathrm{g}}$, Aaron G. Schmidt ${ }^{\mathrm{e}, \mathrm{f}}$, Andrew S. Azman ${ }^{\mathrm{c}}$, Galit Alter ${ }^{\mathrm{e}}$, Edward T Ryan ${ }^{\mathrm{a}, \mathrm{b}, \mathrm{h}}$, Jason B. Harris ${ }^{\mathrm{a}, \mathrm{i}}$, Richelle C. Charles ${ }^{\mathrm{a}, \mathrm{b} \# \dagger}$

${ }^{a}$ Division of Infectious Diseases, Massachusetts General Hospital, Boston, MA, USA

${ }^{b}$ Department of Medicine, Harvard Medical School, Boston, MA, USA

${ }^{c}$ Department of Epidemiology, Johns Hopkins Bloomberg School of Public Health, Baltimore, MD, USA

${ }^{\mathrm{d}}$ Department of Pathology, Massachusetts General Hospital, Boston, MA, USA

${ }^{\mathrm{e}}$ Ragon Institute of MGH, MIT, and Harvard, Cambridge, MA, USA

${ }^{\mathrm{f}}$ Department of Microbiology, Harvard Medical School, Boston, MA, USA

${ }^{g}$ Center for Virology and Vaccine Research, Beth Israel Deaconess Medical Center, Harvard Medical School, Boston, MA, USA

${ }^{\mathrm{h}}$ Department of Immunology and Infectious Diseases, Harvard T.H. Chan School of Public

Health, Boston, MA, USA

i Department of Pediatrics, Harvard Medical School, Boston, MA, USA

Running title: SARS-CoV-2 antibody responses

*\# contributed equally to this work

†Address correspondence to Richelle C. Charles, rcharles@mgh.harvard.edu 
medRxiv preprint doi: https://doi.org/10.1101/2020.07.18.20155374; this version posted July 20, 2020. The copyright holder for this preprint (which was not certified by peer review) is the author/funder, who has granted medRxiv a license to display the preprint in perpetuity.

It is made available under a CC-BY 4.0 International license .

\section{ABSTRACT \\ BACKGROUND}

Characterizing the humoral immune response to SARS-CoV-2 and developing accurate serologic assays are needed for diagnostic purposes and estimating population-level seroprevalence.

\section{METHODS}

We measured the kinetics of early antibody responses to the receptor-binding domain (RBD) of the spike (S) protein of SARS-CoV-2 in a cohort of 259 symptomatic North American patients infected with SARS-CoV-2 (up to 75 days after symptom onset) compared to antibody levels in 1548 individuals whose blood samples were obtained prior to the pandemic.

\section{RESULTS}

Between 14-28 days from onset of symptoms, $\operatorname{IgG}, \operatorname{Ig} \mathrm{A}$, or $\operatorname{IgM}$ antibody responses to RBD were all accurate in identifying recently infected individuals, with $100 \%$ specificity and a sensitivity of $97 \%, 91 \%$, and $81 \%$ respectively. Although the estimated median time to becoming seropositive was similar across isotypes, $\operatorname{IgA}$ and IgM antibodies against RBD were short-lived with most individuals estimated to become seronegative again by 51 and 47 days after symptom onset, respectively. IgG antibodies against RBD lasted longer and persisted through 75 days postsymptoms. IgG antibodies to SARS-CoV-2 RBD were highly correlated with neutralizing antibodies targeting the S protein. No cross-reactivity of the SARS-CoV-2 RBD-targeted antibodies was observed with several known circulating coronaviruses, HKU1, OC 229 E, OC43, and NL63.

\section{CONCLUSIONS}

Among symptomatic SARS-CoV-2 cases, RBD-targeted antibodies can be indicative of previous and recent infection. IgG antibodies are correlated with neutralizing antibodies and are possibly a correlate of protective immunity. 
medRxiv preprint doi: https://doi.org/10.1101/2020.07.18.20155374; this version posted July 20, 2020. The copyright holder for this preprint (which was not certified by peer review) is the author/funder, who has granted medRxiv a license to display the preprint in perpetuity.

It is made available under a CC-BY 4.0 International license.

\section{INTRODUCTION:}

Severe acute respiratory syndrome coronavirus 2 (SARS-CoV-2), the causative agent of coronavirus disease 2019 (COVID-19), has spread rapidly around the world since first identified in Wuhan, China, in December 2019 ${ }^{1}$. On March $11^{\text {th }}, 2020$ the World Health Organization (WHO) declared COVID-19 a pandemic. As of July 13th, 2020, the disease has caused $12,750,275$ confirmed cases and 566,355 deaths globally ${ }^{2}$.

Currently, our understanding of antibody responses following infection with SARS-CoV2 is limited ${ }^{3,4}$, including the magnitude and duration of responses, cross-reactivity with other coronaviruses and viral respiratory pathogens, and correlates of protective immunity following infection. A detailed characterization of antibody responses is needed to determine whether antibody-based tests can augment viral detection-based assays in the diagnosis of active or recent infections and to inform the design and interpretation of seroepidemiologic studies.

In this study, we characterize the kinetics and antibody isotype profile to the receptor binding domain (RBD) of the spike (S) protein of SARS-CoV-2 in a longitudinal cohort of North American patients infected with SARS-CoV-2 and in pre-pandemic controls. We evaluated the sensitivity and specificity of anti-RBD responses in detecting recent infection and estimated the time it takes for cases to become seropositive (seroconversion) or return to seronegative (seroreversion). We also examined how well these responses correlated with neutralizing antibody activity directed at the S protein. Additionally, we evaluated the cross-reactivity of these responses with other coronavirus RBDs and characterize assay performance using dried blood spots.

\section{MATERIALS/ METHODS:}

Plasma/serum/dried blood spot (DBS) samples. Clinical samples were obtained from individuals with PCR confirmed SARS-COV-2 infection presenting to the Massachusetts General Hospital (MGH) in Boston, MA with fever and/or viral respiratory symptoms from March to April 2020 and who met criteria for RT-PCR testing. These criteria changed over time, 
medRxiv preprint doi: https://doi.org/10.1101/2020.07.18.20155374; this version posted July 20, 2020. The copyright holder for this preprint (which was not certified by peer review) is the author/funder, who has granted medRxiv a license to display the preprint in perpetuity.

It is made available under a CC-BY 4.0 International license .

but included patients with severe symptoms requiring hospital admission, who had other risk factors for disease progression (e.g. were age 60 or older, had diabetes, or were immunocompromised), or who worked or lived in a setting where infection control requirements dictated a need for testing. Additional serum/plasma samples collected September 2015 to December 2019, prior to the SARS-COV-2 outbreak, were used as controls. This included healthy adults seen at the MGH Immunization and Travel Clinic prior to travel, patients undergoing routine serology, and patients presenting with other known febrile illnesses. Plasma samples, except for the routine serology samples, were heat-inactivated at $56^{\circ} \mathrm{C}$ for one hour prior to analysis. DBS sample preparation is provided in the Supplementary Material. Patient demographic information, lab results, and clinical outcomes were extracted from the electronic medical record. All research was approved by the Institutional Review Board for Human Subjects Research at MGH.

Enzyme-linked immunosorbent assay (ELISA). The ELISA assays measured IgG, IgA, and IgM responses to the receptor binding domain of the spike protein (RBD) from SARS-CoV-2 [GenBank: MN975262], Middle East Respiratory Syndrome (MERS) virus [GenBank: AFY13307.1], SARS-CoV-1 [GenBank: AAP13441.1], and common cold coronaviruses HKU1 [GenBank: AAT98580.1], OC229E [GenBank: AAK32191], OC43 [GenBank:AAT84362], and NL63 [GenBank: AKT07952]. Anti- RBD-specific antibody concentrations (ug/mL) were quantified using isotype-specific anti-RBD monoclonal antibodies ${ }^{5}$. A full protocol is provided in the Supplementary Material and is available on protocols.io (https://www.protocols.io/view/sars-cov-2-rbd-elisa-bikbkcsn).

Pseudovirus neutralization assay. To determine the SARS-CoV-2 neutralization activity of our plasma samples, we used a lentivirus pseudoneutralization model as previously described ${ }^{6}$, which is a strong correlate of protective immunity in challenged rhesus macaques ${ }^{7}$. We expressed results from this assay as the antibody titer required to neutralize $50 \%$ of the SARSCoV-2 pseudovirus (NT50).

\section{Statistical analysis.}


medRxiv preprint doi: https://doi.org/10.1101/2020.07.18.20155374; this version posted July 20, 2020. The copyright holder for this preprint (which was not certified by peer review) is the author/funder, who has granted medRxiv a license to display the preprint in perpetuity.

It is made available under a CC-BY 4.0 International license .

Single isotype thresholds. We first explored how cutoffs of individual isotypes (IgM, IgG and IgA) performed in identifying previously infected individuals. We compared measurements from pre-pandemic controls, with those taken at any time, $\leq 7$ days, 8-14 days, $>15-28$ days, and $>28$ days after the onset of symptoms. Using a previously described cross-validation procedure ${ }^{8}$, we allocated both cases and controls among 10-folds to calculate a pooled cross-validated AUC (cvAUC). Using the isotype cut-offs defined by the maximum concentration $(\mathrm{ug} / \mathrm{mL})$ found among pre-pandemic controls (IgG: 0.57, IgM: 2.63, IgA: 2.02), we estimated sensitivity and bootstrap $95 \%$ confidence intervals.

Random forest classification models. We explored how combining multiple isotype-specific responses with a random forest classification models performed identifying previously infected individuals. We repeated the same procedures for cross-validation and assessed variable importance within these different models using a permutation test-based metric, mean decrease in accuracy.

Analysis of time to seroconversion and seroreversion. Using the cut-offs defined earlier, we modeled the time required to become seropositive (seroconversion) and return to becoming seronegative (seroreversion). Using individual level interval-censored data, we fit nonparametric (i.e Turnbull's Estimator) and parametric accelerated failure time models using the icenReg R package ${ }^{9}$. All time-to-event data were assumed to be Weibull distributed with bootstrapped $95 \%$ confidence intervals estimated.

All analyses were completed using R (Version 3.6.1) within Rstudio (Version 1.2.5019).

\section{RESULTS}

Study cohorts. We measured RBD responses in two cohorts: 1) symptomatic patients who tested positive for SARS-CoV-2 by PCR $(\mathrm{n}=259)$ and 2$)$ healthy $(\mathrm{n}=1,515)$ and febrile controls $(\mathrm{n}=$ 33) collected prior to the SARS-CoV-2 outbreak. The majority of SARS-CoV-2 positive cases were severe (95\% hospitalized, $31 \%$ requiring ICU level care, $16 \%$ died), male (62\%), and older (median age: 58) (Table 1, Figure S1). Most pre-pandemic controls were younger (median age: 
medRxiv preprint doi: https://doi.org/10.1101/2020.07.18.20155374; this version posted July 20, 2020. The copyright holder for this preprint (which was not certified by peer review) is the author/funder, who has granted medRxiv a license to display the preprint in perpetuity.

It is made available under a CC-BY 4.0 International license .

37 ) and female (62\%). Serum was collected at multiple time points for most patients (56\%; $\mathrm{n}=146)$, with $23 \%(\mathrm{n}=59)$ having $\geq 4$ samples. Forty-nine percent of this cohort had a sample collected between 0-7 days after onset of symptoms $(n=126), 59 \%$ had a sample between 8-14 days $(\mathrm{n}=154), 42 \%$ had a sample between 15-28 days $(\mathrm{n}=110), 22 \%$ had a sample between 29-45 days $(n=56), 8 \%$ had a sample between 46-60 days $(n=20)$ and 3\% had a sample $>60$ days $(n=7)$. The last sample was collected 75 days post-symptom onset.

Kinetics of anti-SARS-CoV-2 RBD antibody responses. Most cases eventually had evidence of elevated antibodies to SARS-CoV-2 compared to pre-pandemic controls (Figure 1). From days 5 to 14, there was a sharp rise in RBD-specific antibodies of all isotypes, and IgG titers continued to rise until day 25 after the onset of symptoms (Figure S2A). The population average IgA and IgM responses peaked a few days earlier than IgG and then declined towards levels measured in pre-pandemic samples (Figure S2 and S3). IgG antibody responses also began to wane, but at a slower rate. Among 58 cases with $\geq 4$ measurements, the individual peak measurement IgM often occurred before that of $\operatorname{IgG}$ (Before: 48\%, Same: 48\%) and simultaneously with that of $\operatorname{IgA}$ (Before: 22\%, Same: 62\%). Among hospitalized patients, the population average trajectory differed little between severity levels; the average IgM levels among hospitalized cases admitted to the ICU dropped more quickly than that of patients not requiring the ICU or who died (Figure S2B).

Accuracy of RBD antibodies for identifying recent SARS-CoV-2 infection. Each antibody isotype was predictive of infection, and the cross-validated AUC (cvAUC) of antibody testing for each antibody isotype increased to above 97\% during the period of 15-28 days after symptom onset (Table 2). The cvAUC remained high for $\mathrm{IgG}$ after 28 days but began to fall for $\mathrm{IgM}$ and IgA. Using the pre-defined cutoffs, the sensitivity of IgG antibodies rose from $7 \%$ (<=7days) to $97 \%$ after 14 days of symptoms. The sensitivity of $\operatorname{IgA}$ and $\operatorname{IgM}$ rose to $91 \%$ and $81 \% 2-4$ weeks post-symptom onset but dropped after 4 weeks to $57 \%$ and $40 \%$, respectively.

\section{Combining multiple isotype measurements to improve predictive accuracy. The}

discriminatory power of IgG alone was high after 14 days; however, we found the accuracy of ELISA-based identification of recent infections could be improved by adding IgM and/or IgA at 
medRxiv preprint doi: https://doi.org/10.1101/2020.07.18.20155374; this version posted July 20, 2020. The copyright holder for this preprint (which was not certified by peer review) is the author/funder, who has granted medRxiv a license to display the preprint in perpetuity. It is made available under a CC-BY 4.0 International license .

the earlier phases of infection (Table S1; Figure S4). The random forest model cvAUC was 0.91 for $\operatorname{IgG}$ and $\operatorname{IgM}$ and 0.91 for $\operatorname{IgG}$ and $\operatorname{IgA}$ at 8-14 days post-symptom onset. These models provide an estimate of the contribution of each antibody isotype, as well as the maximum predictive value of combined measures of anti-RBD $\operatorname{IgG}$, IgA and IgM responses. While $\operatorname{IgM}$ levels contributed the most to prediction of recent infection in the early phase of illness, $\mathrm{IgG}$ responses were the most predictive of infection 8 or more days after the onset of symptoms. Using the pre-determined thresholds for seropositivity for each antibody isotype, out of the 223 patients with samples collected during early infection ( $<14$ days post symptom onset), we were able to identify an additional 14 cases by adding IgM, 15 by adding IgA, and 23 by adding both $\operatorname{IgM}$ and $\operatorname{IgA}$.

Estimation of time to seroconversion and seroreversion for each isotype. Of 94 cases with samples after 20 days post-symptoms, most had evidence of seroconversion for all isotypes (IgG: 99\%, IgM: 90\%, IgA: 96\%). The estimated median time to seroconversion from symptom onset was comparable across antibody isotype: 10.9 days (95\% CI:10.0-11.9) for IgG, 11.8 days (10.713.1) for IgA and 12.1 (10.8-13.7 days) for IgM (Figure 2). On average, most hospitalized individuals seroconverted at least two days sooner to all isotypes compared to non-hospitalized patients, while age and sex appeared to have little effect (Table S2). Of seroconverted cases with samples 40 days post-symptoms or after, most eventually had $\operatorname{IgM}(21 / 27)$ and $\operatorname{IgA}(18 / 27)$ seronegative measurements. Only 1 of 29 (an immunosuppressed individual) cases seroreverted for IgG. We estimated the median time to seroreversion for IgM was 46.9 days (95\% CI: 41.1 54.8), with the first $5 \%$ seroreverting by 24 days. Similarly, we estimate a median seroreversion time for anti-RBD IgA to be 51.0 days (95\% CI: 45.7 - 57.1), with the first 5\% seroreverting by 29.8 days (Figure 2).

\section{Association between RBD responses and the development of neutralizing antibodies}

targeting the $\mathbf{S}$ protein. We measured pseudoneutralizing antibodies targeting the SARS-CoV2 S protein in 88 samples from 15 individuals collected between 0 and 75 days post-symptoms (Figure 3). Over the course of infection, all patients tested developed detectable neutralizing antibodies (NAb). NAb titers were correlated with the concentration of anti-RBD IgG $(r=0.87)$. 
medRxiv preprint doi: https://doi.org/10.1101/2020.07.18.20155374; this version posted July 20, 2020. The copyright holder for this preprint (which was not certified by peer review) is the author/funder, who has granted medRxiv a license to display the preprint in perpetuity.

It is made available under a CC-BY 4.0 International license .

Of note, similar to anti-RBD IgG responses, NAb titers plateaued and remained detectable at later time points despite the more rapid decline of $\operatorname{IgA}$ and $\operatorname{IgM}$ responses.

Evaluation of cross-reactivity with other coronaviruses. We evaluated antibody responses to RBDs derived from spike proteins of endemic human coronaviruses (CoVs) (i.e. HKU1, CoV OC 229E, OC43, and NL63), severe acute respiratory syndrome coronavirus (SARS-CoV-1) and Middle East Respiratory Syndrome coronavirus (MERS-CoV) (Figure S6). We did not observe a cross-reactive response to the endemic human coronaviruses in individuals infected with SARS$\mathrm{CoV}-2$, and antibody responses to these CoVs were comparable between pre-pandemic controls and individuals with COVID-19 at all phases of infection. We observed significant crossreactivity to SARS-CoV-1 RBD in individuals with COVID-19, but no cross-reactive responses to the MERS-CoV RBD.

Comparison of plasma responses to dried blood spots (DBS). Since this assay could be used in large serosurveys, we also evaluated the assay with dried blood spot eluates in a subset of patients ( $n=20$ at two timepoints; 40 samples) and pre-pandemic controls $(n=20)$. The anti-RBD IgG DBS measurements had a high degree of linear correlation in both cases and control plasma $(\mathrm{r}=0.99$, Figure S7). While the classification of all samples was the same between DBS and plasma samples ( $100 \%$ classification concordance), values between the two media diverged more at low titer values.

\section{DISCUSSION}

In this study, we found that the presence of antibodies against the RBD region of the $\mathrm{S}$ protein was highly predictive of SARS-CoV-2 infection. Specifically, the presence of IgG antibodies targeting SARS-CoV-2 RBD was a highly specific (100\%) and sensitive (97\%) marker of infection after 14 days from onset of illness. IgG seropositivity was sustained in patients up to 75 days (last time point measured), and the concentration of these antibodies was highly correlated with pseudovirus NAb titers. In contrast, IgM and IgA responses to RBD were short-lived and with many individuals seroreverting within two months of the onset of illness. Longer term follow-up is needed to determine the duration of $\mathrm{IgG}$ responses. 
medRxiv preprint doi: https://doi.org/10.1101/2020.07.18.20155374; this version posted July 20, 2020. The copyright holder for this preprint (which was not certified by peer review) is the author/funder, who has granted medRxiv a license to display the preprint in perpetuity.

It is made available under a CC-BY 4.0 International license.

RT-PCR based detection of SARS-CoV-2 is sensitive early in the first week after the onset of symptoms ${ }^{10}$, and our results suggest that the detection of antibodies against the SARSCoV-2 RBD by ELISA is not likely to contribute significantly to the early diagnosis of COVID19. Even models incorporating all isotypes had limited predictive capacity during the first week of illness. However, our results do demonstrate that the detection of $\operatorname{IgM}$ and $\operatorname{IgA}$ responses improved the sensitivity of serologic testing within two weeks of the onset of symptoms. Beyond two weeks after symptom onset, supplementing viral detection assays with antibody-based testing methods clearly increases sensitivity in diagnosing recent infection ${ }^{11,12}$, particularly as the sensitivity of RT-PCR for SARS-CoV-2 infection wanes ${ }^{13}$. Our results, also, show that the early seroreversion of $\operatorname{Ig} \mathrm{A}$ and $\operatorname{IgM}$ responses could be useful in the future in distinguishing previous infection from acute COVID-19. Taken together, these findings suggest specific and clearly defined applications for serologic testing of RBD responses in the clinical setting.

Testing for anti-SARS-CoV-2 RBD antibodies can also be applied in seroepidemiologic studies, even in areas of low prevalence, given their excellent specificity and defined kinetics. Variation in the performance of commercial serologic tests and confusion about the role of antibodies as biomarkers of past infection versus protective immunity has led to widespread misperception that antibody testing may not be accurate or useful ${ }^{14,15}$. In contrast, our study, based on a large sample of cases and controls should provide significant confidence in the potential contribution of serologic measures in public health efforts to identify transmission hotspots and at-risk populations. In addition, the lack of cross-reactivity of SARS-CoV-2 RBD with common cold coronaviruses should provide additional confidence in the specificity of the assay. Longer term characterization of $\mathrm{IgG}$ responses, however, is still needed to assist in design and interpretation of serosurveys.

One notable limitation of our study was that our cohort of individuals with SARS-CoV-2 infection was skewed toward adults with clinically significant disease or with risk factors for disease progression. Individuals with mild or asymptomatic infection have been shown to develop less robust antibody responses ${ }^{13}$, which may lead to false negatives if our proposed assay thresholds are used. Individuals with mild or asymptomatic infection may also serorevert 
medRxiv preprint doi: https://doi.org/10.1101/2020.07.18.20155374; this version posted July 20, 2020. The copyright holder for this preprint

quicker than symptomatic individuals ${ }^{13}$. The gradation of responses by disease severity has been found in other infections, including SARS-CoV-2 ${ }^{13}$ and MERS-CoV infection ${ }^{16}$. An association between disease severity and the kinetics of the antibody response is also suggested by our finding that individuals with more severe disease, who required ICU-level care, seroconverted earlier than individuals who did not require ICU-level support.

It is important to note that our assay identifies individuals with recent SARS-CoV-2 infection but does not provide information about whether individuals are protected from subsequent infection. Optimal immunologic correlates of protection for SARS-CoV-2 remain unknown in humans. In many human challenge studies of common cold coronavirus infection, the presence of pre-existing neutralizing antibodies has been associated with protection against the development of symptomatic infection and with decreased viral shedding ${ }^{17}$. In addition, in vaccinated rhesus macaques challenged with SARS-CoV-2 infection, neutralizing antibodies directed at the $S$ protein were also a strong correlate of protective immunity ${ }^{6}$. Thus, neutralization titers, in the absence of other known markers, has become a de facto immunologic marker of protection pending further investigation; however, whether there is a threshold titer that is robustly associated with protection remains unclear. Nonetheless, it is notable that antiRBD IgG antibodies were strongly correlated with the neutralizing antibodies associated with protection in vaccinated macaques ${ }^{6}$. This correlation with neutralizing titers was stronger than observed for other previously tested commercial serologic assays ${ }^{18}$.

Our results, therefore, provide strong support for the application of anti-RBD antibodies as a marker of recent SARS-CoV-2 infection. This approach meets the CDC's interim guidelines for serologic testing ${ }^{19}$ and has the potential to facilitate accurate diagnosis in clinical settings and the implementation of population-based studies of previous infection globally. While the association between RBD-IgG with neutralizing titers and the persistence of these antibodies at late time points is encouraging, further work is needed to define the optimal antibody mediated correlates of protective immunity. 
medRxiv preprint doi: https://doi.org/10.1101/2020.07.18.20155374; this version posted July 20, 2020. The copyright holder for this preprint (which was not certified by peer review) is the author/funder, who has granted medRxiv a license to display the preprint in perpetuity.

It is made available under a CC-BY 4.0 International license.

\section{FUNDING AND DISCLOSURES}

This work was supported in part by Centers for Disease Control and Prevention (U01CK000490

to E.T.R, R.C.L., R.C.C, J.B.H, G.M., E.O., S.E.T.), the National Institutes of Health (R01

AI146779 to A.G.S; T32 GM007753 to B.M.H and T.M.C.; T32 AI007245 to J.F) and

MassCPR grant to A.G.S.

\section{REFERENCES}

1. Lipsitch M, Swerdlow DL, Finelli L. Defining the Epidemiology of Covid-19 - Studies

Needed. N Engl J Med 2020;382:1194-6.

2. WHO Coronavirus Disease (COVID-19) Dashboard. A https://covid19.who.int/.

Accessed 14th July,2020.

3. Zohar T, Alter G. Dissecting antibody-mediated protection against SARS-CoV-2. Nat

Rev Immunol 2020;20:392-4.

4. Dohla M, Boesecke C, Schulte B, et al. Rapid point-of-care testing for SARS-CoV-2 in a community screening setting shows low sensitivity. Public Health 2020;182:170-2.

5. Wang C, Li W, Drabek D, et al. Publisher Correction: A human monoclonal antibody blocking SARS-CoV-2 infection. Nat Commun 2020;11:2511.

6. Chandrashekar A, Liu J, Martinot AJ, et al. SARS-CoV-2 infection protects against rechallenge in rhesus macaques. Science 2020. Published online 2020 May 20.

doi: $10.1126 /$ science.abc4776

7. Yu J, Tostanoski LH, Peter L, et al. DNA vaccine protection against SARS-CoV-2 in rhesus macaques. Science 2020. doi: 10.1126/science.abc6284 
medRxiv preprint doi: https://doi.org/10.1101/2020.07.18.20155374; this version posted July 20, 2020. The copyright holder for this preprint (which was not certified by peer review) is the author/funder, who has granted medRxiv a license to display the preprint in perpetuity.

It is made available under a CC-BY 4.0 International license .

8. Bryant JE, Azman AS, Ferrari MJ, et al. Serology for SARS-CoV-2: Apprehensions, opportunities, and the path forward. Sci Immunol 2020;5. doi: 10.1126/sciimmunol.abc6347

9. Anderson-Bergman C. icenReg: Regression Models for Interval Censored Data in R. 2017. https://www.jstatsoft.org/article/view/v081i12

10. Kucirka LM, Lauer SA, Laeyendecker O, Boon D, Lessler J. Variation in False-Negative Rate of Reverse Transcriptase Polymerase Chain Reaction-Based SARS-CoV-2 Tests by Time Since Exposure. Ann Intern Med 2020. Published online 2020 May 13. doi: 10.7326/M20-1495

11. Guo L, Ren L, Yang S, et al. Profiling Early Humoral Response to Diagnose Novel Coronavirus Disease (COVID-19). Clin Infect Dis 2020. Published online 2020 Mar 21. doi: $10.1093 / \mathrm{cid} / \mathrm{ciaa} 310$

12. Yong SEF, Anderson DE, Wei WE, et al. Connecting clusters of COVID-19: an epidemiological and serological investigation. Lancet Infect Dis 2020. doi:https://doi.org/10.1016/S1473-3099(20)30273-5

13. Long QX, Tang XJ, Shi QL, et al. Clinical and immunological assessment of asymptomatic SARS-CoV-2 infections. Nat Med 2020. doi: 10.1038/s41591-020-0965-6

14. Antibody Test, Seen as Key to Reopening Country, Does Not Yet Deliver. The New York Times Published April 19, 2020.

15. Antibody tests for Covid-19 wrong up to half the time, CDC says. Published CNN May 26, 2020.

16. Ko JH, Muller MA, Seok H, et al. Serologic responses of 42 MERS-coronavirus-infected patients according to the disease severity. Diagn Microbiol Infect Dis 2017;89:106-11. 
medRxiv preprint doi: https://doi.org/10.1101/2020.07.18.20155374; this version posted July 20, 2020. The copyright holder for this preprint (which was not certified by peer review) is the author/funder, who has granted medRxiv a license to display the preprint in perpetuity.

It is made available under a CC-BY 4.0 International license .

17. Huang AT, Garcia-Carreras B, Hitchings MDT, et al. A systematic review of antibody mediated immunity to coronaviruses: antibody kinetics, correlates of protection, and association of antibody responses with severity of disease. medRxiv 2020. Preprint. 2020 Apr 17. doi: 10.1101/2020.04.14.20065771

18. Elena Criscuolo RAD, Marta Strollo, Serena Rolla et al. Poor correlation between antibody titers and neutralizing activity in sera from SARS-CoV-2 infected subjects. medRxiv. 2020. Preprint. 2020 July 11 2020. doi: https://doi.org/10.1101/2020.07.10.20150375

19. Centers for Disease Control and Prevention. Interim Guidelines for COVID-19 Antibody Testing. 2020. at https://www.cdc.gov/coronavirus/2019-ncov/lab/resources/antibody-testsguidelines.html. Accessed 13th, July 2020. 


\section{TABLES}

Table 1. Individual characteristics of PCR-positive SARS-CoV-2 cases and pre-pandemic controls

\begin{tabular}{lcc}
\hline \multicolumn{1}{c}{ Characteristic } & $\begin{array}{c}\text { Pre-pandemic } \\
\text { Controls* } \\
(\mathrm{N}=1,548)\end{array}$ & $\begin{array}{c}\text { PCR-positive } \\
\text { Cases } \\
(\mathrm{N}=259)\end{array}$ \\
\hline Age & & \\
$\quad$ Median [IQR] & $37[30-54]$ & $58[44-72]$ \\
$<65$ years (\%) & $1,386(90)$ & $160(62)$ \\
$65+$ years (\%) & $162(10)$ & $99(38)$ \\
Female (\%) & $1,024(66)$ & $98(38)$ \\
Immunocompromised (\%) & NA & $17(7)$ \\
Severity & & $14(5)$ \\
Not Hospitalized (\%) & NA & $122(47)$ \\
Hospitalized, no ICU (\%) & NA & $81(31)$ \\
Hospitalized, required ICU & NA & $41(16)$ \\
(\%) & NA & $1(0)$ \\
Died due to COVID-19 (\%) & NA & \\
Missing Severity (\%) & &
\end{tabular}

*Pre-pandemic controls included healthy adults $(\mathrm{n}=278)$, patients undergoing routine serology testing $(\mathrm{n}=1241)$, and patients presenting with other known febrile illnesses $(\mathrm{n}=33)$, including 13 with bacteremia (e.g. S. aureus, $S$. pneumoniae, E. coli, or K. pneumoniae confirmed by standard microbiologic techniques), 4 with babesiosis (confirmed by microscopy and/or PCR), 1 with presumed scrub typhus, and 15 with viral respiratory infections (e.g. influenza [7], parainfluenza [4], respiratory syncytial virus [3], and metapneumovirus [1] confirmed by PCR or direct fluorescent antibody test 
Table 2. Predictive accuracy of individual isotypes for classifying controls and cases across time.

\begin{tabular}{rrrr}
\hline Isotype & Days since symptom onset & cvAUC $(95 \% \mathrm{Cl})$ & Sensitivity $(95 \% \mathrm{Cl})^{\star}$ \\
\hline $\lg \mathrm{G}$ & $\leq 7$ days & $0.65(0.55-0.75)$ & $0.07(0.03-0.13)$ \\
& $8-14$ days & $0.88(0.82-0.94)$ & $0.52(0.44-0.60)$ \\
$15-28$ days & $0.99(0.96-1.00)$ & $0.97(0.95-1.00)$ \\
& $>28$ days & $0.98(0.95-1.00)$ & $0.97(0.93-1.00)$ \\
$\lg \mathrm{A}$ & $\leq 7$ days & $0.60(0.50-0.70)$ & $0.08(0.04-0.13)$ \\
& $8-14$ days & $0.86(0.79-0.93)$ & $0.51(0.43-0.59)$ \\
& $15-28$ days & $0.98(0.94-1.00)$ & $0.91(0.85-0.96)$ \\
& $>28$ days & $0.96(0.90-1.00)$ & $0.57(0.44-0.69)$ \\
$\lg \mathrm{M}$ & $\leq 7$ days & $0.60(0.50-0.70)$ & $0.07(0.03-0.12)$ \\
& $8-14$ days & $0.85(0.79-0.92)$ & $0.51(0.43-0.59)$ \\
& $15-28$ days & $0.97(0.93-1.00)$ & $0.81(0.74-0.88)$ \\
& $>28$ days & $0.89(0.80-0.98)$ & $0.40(0.27-0.53)$ \\
\hline
\end{tabular}

* The isotype cut-offs chosen for calculating sensitivity were the maximum value found among pre-pandemic controls (IgG: $0.57 \mu \mathrm{g} / \mathrm{mL}$, IgM: $2.64 \mu \mathrm{g} / \mathrm{mL}$, IgA: 2.02 $\mu \mathrm{g} / \mathrm{mL}$ ). Bootstrap $95 \%$ confidence intervals are shown in parentheses. 
medRxiv preprint doi: https://doi.org/10.1101/2020.07.18.20155374; this version posted July 20, 2020. The copyright holder for this preprint (which was not certified by peer review) is the author/funder, who has granted medRxiv a license to display the preprint in perpetuity.

It is made available under a CC-BY 4.0 International license .

\section{FIGURES}

Figure 1. Measurements of IgG, IgM, and IgA against SARS-CoV-2 spike protein receptor binding domain among pre-pandemic controls and PCR positive cases. Each dot represents a unique measurement of an isotype (Row A: $\operatorname{IgG}$, Row B: $\operatorname{IgM}$, Row C: $\operatorname{Ig} \mathrm{A}$ ) in pre-pandemic controls (left panels) and PCR positive cases (right panels). The blue line is a loess smooth nonparametric function. Black dashed lines indicate the maximum concentration $(\mu \mathrm{g} / \mathrm{mL})$ found among pre-pandemic controls (IgG: 0.57, IgM: 2.63, IgA: 2.02). Horizontal jitter was introduced into the pre-pandemic controls. The limit of detection $(\mu \mathrm{g} / \mathrm{mL})$ was 0.04 for $\operatorname{IgG}, 0.28$ for $\operatorname{IgM}$, and 0.3 for $\operatorname{Ig} \mathrm{A}$.

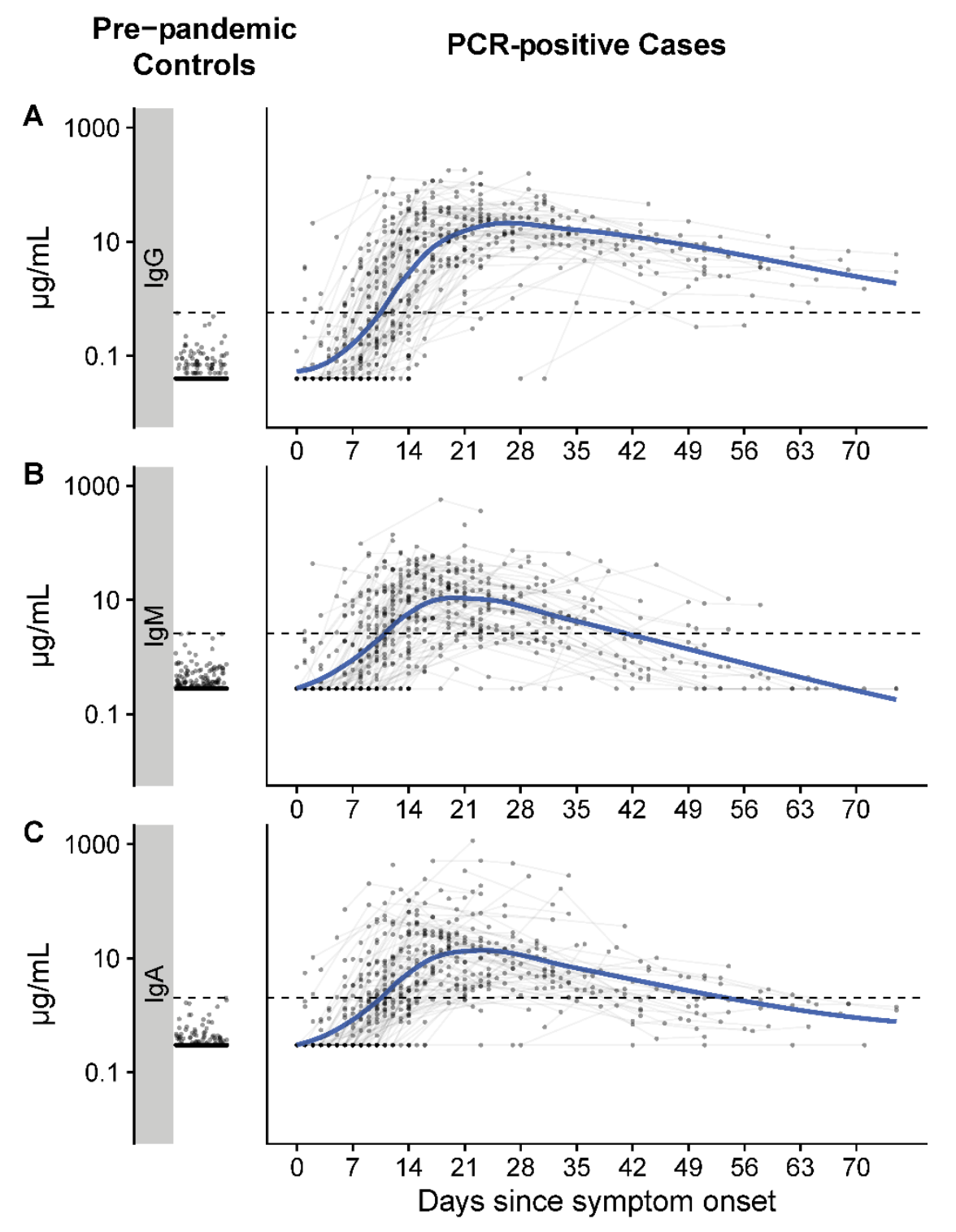


medRxiv preprint doi: https://doi.org/10.1101/2020.07.18.20155374; this version posted July 20, 2020. The copyright holder for this preprint (which was not certified by peer review) is the author/funder, who has granted medRxiv a license to display the preprint in perpetuity.

It is made available under a CC-BY 4.0 International license. 
medRxiv preprint doi: https://doi.org/10.1101/2020.07.18.20155374; this version posted July 20, 2020. The copyright holder for this preprint (which was not certified by peer review) is the author/funder, who has granted medRxiv a license to display the preprint in perpetuity.

It is made available under a CC-BY 4.0 International license.

Figure 2. Parametric and non-parametric model estimates of time to seroconversion and seroreversion for each isotype. A) The isotype cut-offs chosen for seroconversion were the maximum concentration $(\mu \mathrm{g} / \mathrm{mL})$ found among pre-pandemic controls (IgG: 0.57, IgM: 2.63, $\operatorname{IgA:} 2.02)$. The solid line represents the estimated cumulative distribution function of the time to seroconversion or reversion with 100 bootstrapped fits shown as transparent lines. The parametric accelerated failure time models assume a Weibull time-to-event distribution. Nonparametric estimates shown in grey were calculated using the Turnbull method. Only 1 individual seroreverted for IgG, so no model is included. B) The table indicates the estimated average number of days since onset of symptoms it takes for a percentage of cases to seroconvert or serorevert. Bootstrap 95\% confidence intervals are shown in parentheses.

A

Time to seroconversion
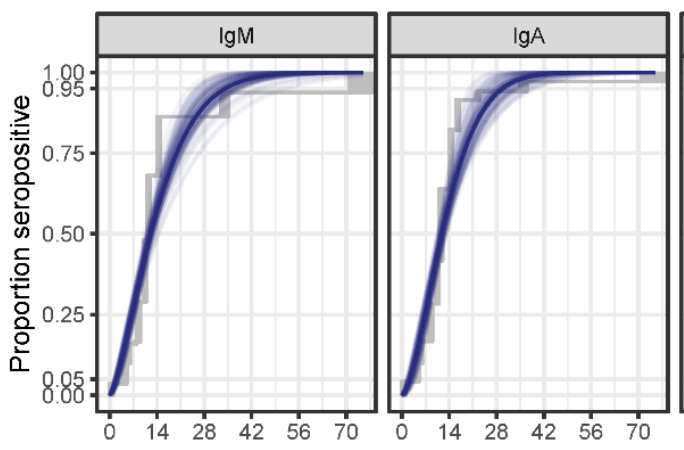

Time to seroreversion
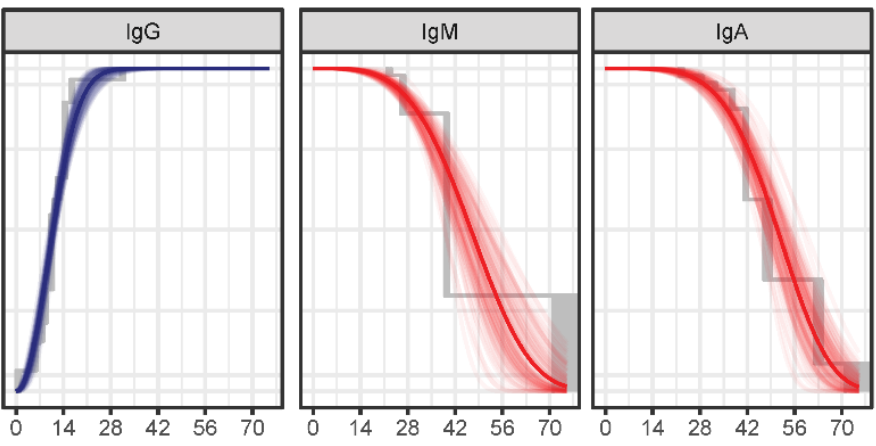

Days since symptom onset

B

\begin{tabular}{ccccccc}
\hline \multirow{2}{*}{ Type } & Isotype & $\begin{array}{c}\text { 5th } \\
\text { Percentile }\end{array}$ & $\begin{array}{c}\text { 25th } \\
\text { Percentile }\end{array}$ & $\begin{array}{c}\text { 50th } \\
\text { Percentile }\end{array}$ & $\begin{array}{c}\text { 75th } \\
\text { Percentile }\end{array}$ & $\begin{array}{c}\text { 95th } \\
\text { Percentile }\end{array}$ \\
\hline Seroconversion & IgA & 2.5 & 6.9 & 11.8 & 18.0 & 28.9 \\
& & $(1.6-3.9)$ & $(5.8-8.1)$ & $(10.6-13.0)$ & $(15.1-21.1)$ & $(20.9-37.7)$ \\
& IgG & 3.2 & 7.2 & 10.9 & 15.2 & 21.9 \\
& & $(2.3-4.4)$ & $(6.2-8.3)$ & $(10.0-11.9)$ & $(13.8-16.7)$ & $(18.5-25.7)$ \\
Seroreversion & IgM & 2.0 & 6.6 & 12.1 & 19.7 & 33.9 \\
& & $(1.3-3.0)$ & $(5.5-7.7)$ & $(10.8-13.7)$ & $(16.3-23.7)$ & $(25.0-45.7)$ \\
& & 29.9 & 42.6 & 51.1 & 59.0 & 69.2 \\
& & $(25.7-34.8)$ & $(38.7-47.2)$ & $(45.9-57.0)$ & $(51.0-67.0)$ & $(57.3-80.4)$ \\
& IgM & 24.0 & 37.3 & 46.7 & 55.8 & 68.1 \\
& & $(21.1-27.5)$ & $(33.7-42.6)$ & $(40.6-54.5)$ & $(46.6-67.5)$ & $(53.8-85.0)$ \\
\hline
\end{tabular}


medRxiv preprint doi: https://doi.org/10.1101/2020.07.18.20155374; this version posted July 20, 2020. The copyright holder for this preprint (which was not certified by peer review) is the author/funder, who has granted medRxiv a license to display the preprint in perpetuity.

It is made available under a CC-BY 4.0 International license.

Figure 3. SARS-CoV-2 pseudovirus neutralization antibody titers in symptomatic PCR positive cases and correlation with anti-RBD IgG responses. A) Each point represents a measurement of 50\% neutralizing titer (NT50). Lines connect measurements from the same individual and a loess smooth function is shown in blue. B) The overall repeated measures correlation coefficient (r) is shown. Lines represent simple linear models for each time period.
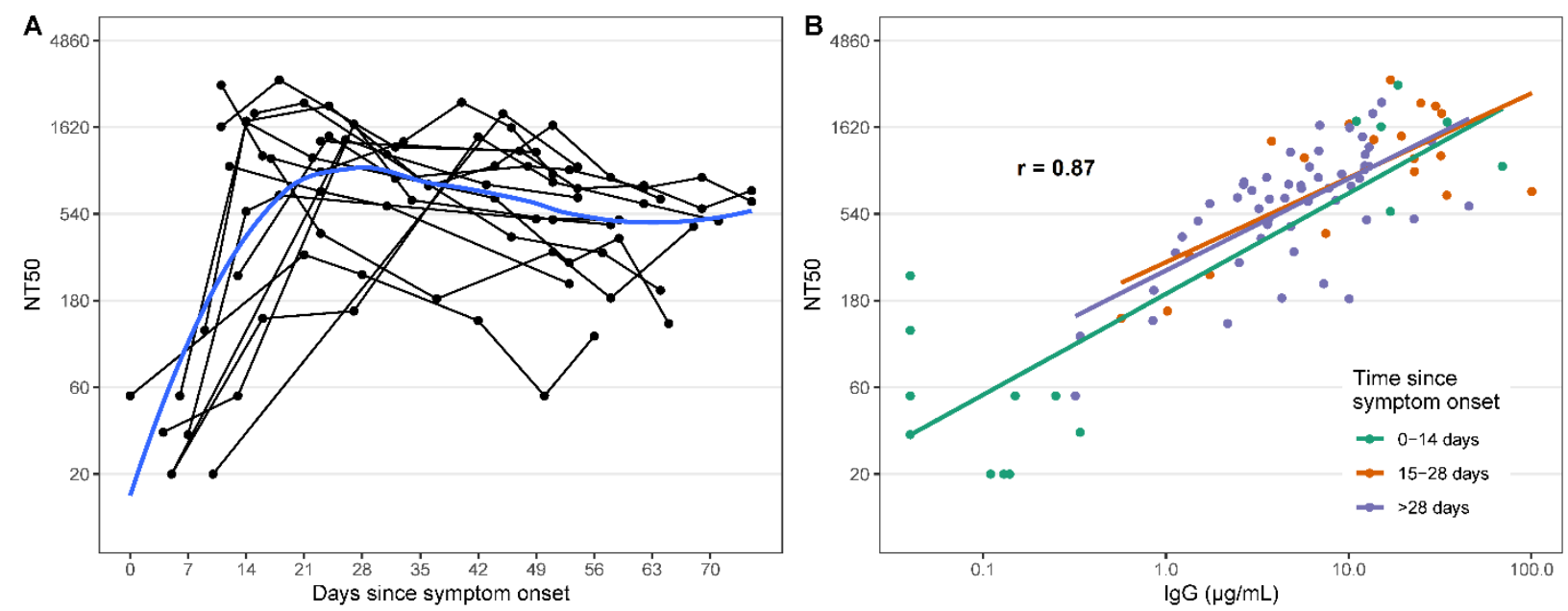
medRxiv preprint doi: https://doi.org/10.1101/2020.07.18.20155374; this version posted July 20, 2020. The copyright holder for this preprint (which was not certified by peer review) is the author/funder, who has granted medRxiv a license to display the preprint in perpetuity.

It is made available under a CC-BY 4.0 International license.

\section{Supplementary Materials}


medRxiv preprint doi: https://doi.org/10.1101/2020.07.18.20155374; this version posted July 20, 2020. The copyright holder for this preprint (which was not certified by peer review) is the author/funder, who has granted medRxiv a license to display the preprint in perpetuity.

It is made available under a CC-BY 4.0 International license .

\section{Method S1. Additional details on laboratory assays}

\section{Enzyme-linked immunosorbent assay (ELISA). The RBDs were expressed in Expi293F}

suspension cells with a C-terminal SBP-His8X tag, and purified using affinity chromatography and then size exclusion chromatography prior to removal of the His tag as described previously ${ }^{1}$. Briefly, 384 well Nunc MaxiSorp plates (Invitrogen, Carlsbad, CA) were coated by adding $50 \mu \mathrm{L}$ of RBD in carbonate buffer $(1 \mu \mathrm{g} / \mathrm{mL})$ and incubating for 1 hour at room temperature (RT). Plates were then blocked for 30 minutes at RT with $5 \%$ non-fat milk in trisbuffered saline (TBS). Diluted samples (1:100 in TBS with $5 \%$ milk, $0.5 \%$ Tween) were added to the plate $(25 \mu \mathrm{L} /$ well $)$ and incubated for 1 hour at $37^{\circ} \mathrm{C}$ with shaking. Serial 4 -fold dilutions to 1:6400 were also included for individuals with high titers. Goat anti-human IgA, IgG, and IgMhorseradish peroxidase conjugated secondary antibodies diluted (Jackson ImmunoResearch, West Grove, PA) at 1:10000 (IgG, IgM) or 1:5000 (IgA) in 5\% milk in TBST were then added to plates ( $25 \mu \mathrm{L} /$ well) and incubated at RT with shaking for 30 minutes. Bound secondaries were detected using 1-step Ultra TMB (tetramethylbenzidine; ThermoScientific, Waltham, MA, 25 $\mu \mathrm{L} /$ well). Plates were incubated at RT for 5 minutes in the dark before addition of $2 \mathrm{~N}$ sulfuric acid stop solution ( $25 \mu \mathrm{L} /$ well). The optical density (OD) was read at $450 \mathrm{~nm}$ and $570 \mathrm{~nm}$ on a plate reader. OD values were adjusted by subtracting the $570 \mathrm{~nm}$ OD from the $450 \mathrm{~nm}$ OD. We used a standard curve of the anti-SARS-CoV-2 monoclonal, CR3022 ${ }^{2}$,to calculate the concentration of anti-RBD IgG, IgA, and IgM expressed in $\mu \mathrm{g} / \mathrm{mL}$.

Dried blood spots (DBS). Single donor, sero-negative whole blood, collected in sodium heparin tubes (Becton, Dickinson, NJ), was spiked with heat-inactivated plasma from SARS-CoV-2 patients. Forty microliter $(40 \mu \mathrm{L})$ droplets were spotted in replicate onto Whatman 903 Protein Saver cards (GE Healthcare, Cardiff, UK). Cards were left to dry overnight at ambient room temperature. The following day, two 6- $\mathrm{mm}^{2}$ punches were removed from the DBS card using a manual hole-punch and eluted overnight at $4^{\circ} \mathrm{C}$ with gentle agitation in $133 \mu \mathrm{L}$ PBS-0.05\% Tween 20 pH 7.4 (Sigma-Aldrich, St. Louis, MO). 
medRxiv preprint doi: https://doi.org/10.1101/2020.07.18.20155374; this version posted July 20, 2020. The copyright holder for this preprint (which was not certified by peer review) is the author/funder, who has granted medRxiv a license to display the preprint in perpetuity.

It is made available under a CC-BY 4.0 International license .

\section{References}

1. Norman M, Gilboa T, Ogata AF, et al. Ultra-Sensitive High-Resolution Profiling of AntiSARS-CoV-2 Antibodies for Detecting Early Seroconversion in COVID-19 Patients. medRxiv 2020.

2. Wang C, Li W, Drabek D, et al. Publisher Correction: A human monoclonal antibody blocking SARS-CoV-2 infection. Nat Commun 2020;11:2511. 
medRxiv preprint doi: https://doi.org/10.1101/2020.07.18.20155374; this version posted July 20, 2020. The copyright holder for this preprint (which was not certified by peer review) is the author/funder, who has granted medRxiv a license to display the preprint in perpetuity.

It is made available under a CC-BY 4.0 International license .

Figure S1: Number of PCR positive cases with a sample taken during each week since symptom onset.

The date of symptom onset could not be determined for three individuals and the severity index was missing for one individual

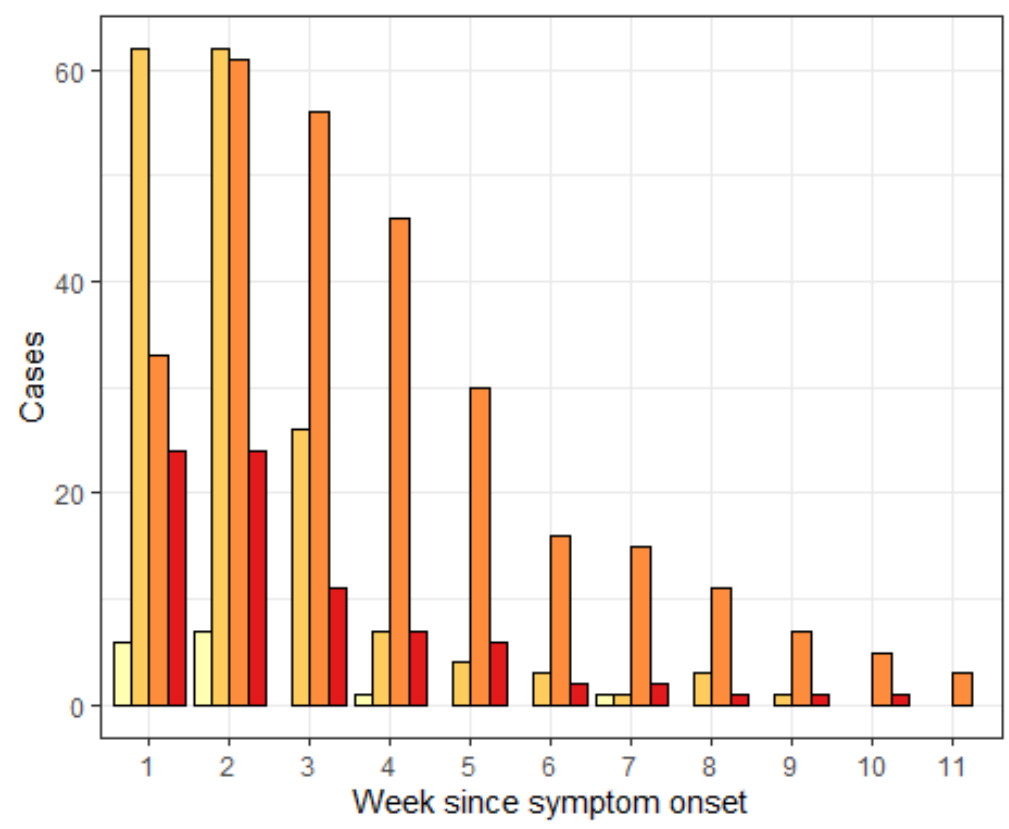

Severity

$\square$ Not Hospitalized

Hospitalized, no ICU

Hospitalized, required ICU

Died due to COVID-19 
Figure S2. Smooth average measurements of $\lg G$, $\lg M$, and $\lg A$ against SARS-CoV-2 spike protein receptor binding domain among PCR positive cases across time.

Limit of detection was artificially set at $0.3 \mu \mathrm{g} / \mathrm{mL}$ for $\operatorname{lgM}$ and $\operatorname{lgG}$ to match that of IgA. Points were jittered horizontally. A) All cases are shown. B) Cases are categorized by clinical severity.

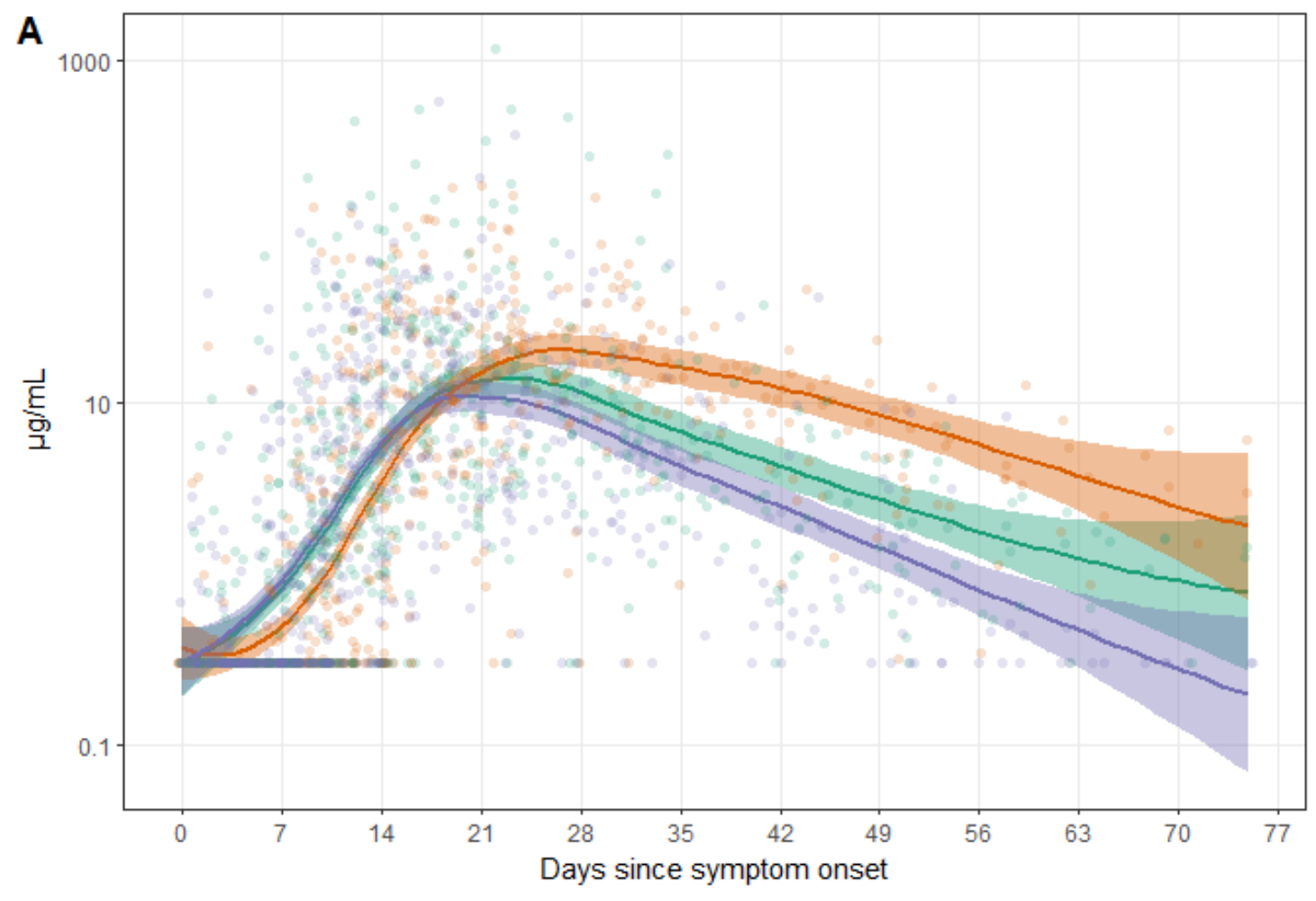

Isotype $-\operatorname{IgA}-\operatorname{IgG}-\operatorname{Ig} M$
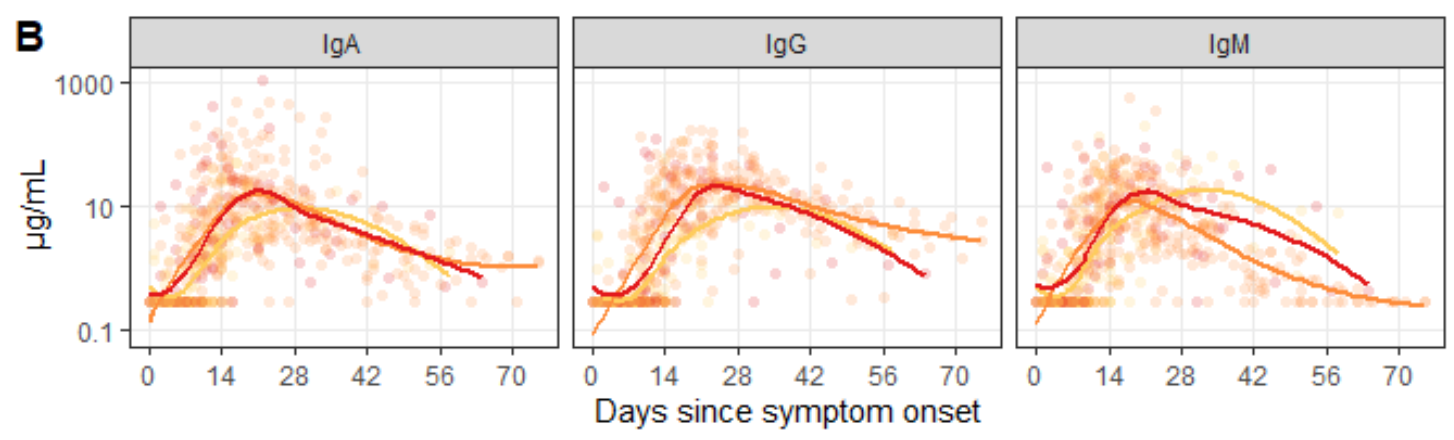

Severity - Hospitalized, no ICU - Hospitalized, required ICU - Died due to COVID-19 
Figure S3. Individual trajectories for 16 randomly selected individuals with 4 or more measurements.

Patient ID numbers are shown in greys boxes.
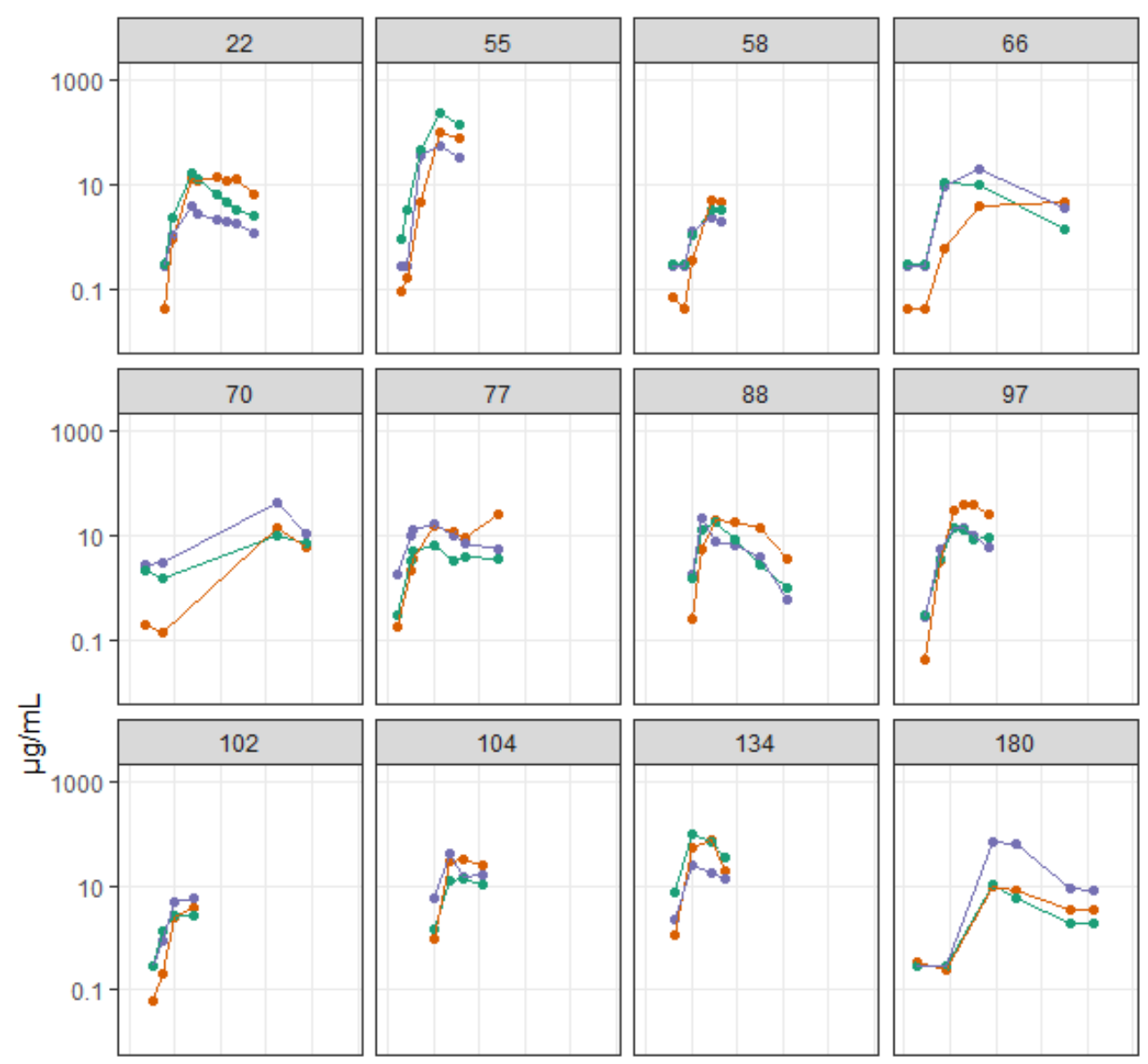

Isotype
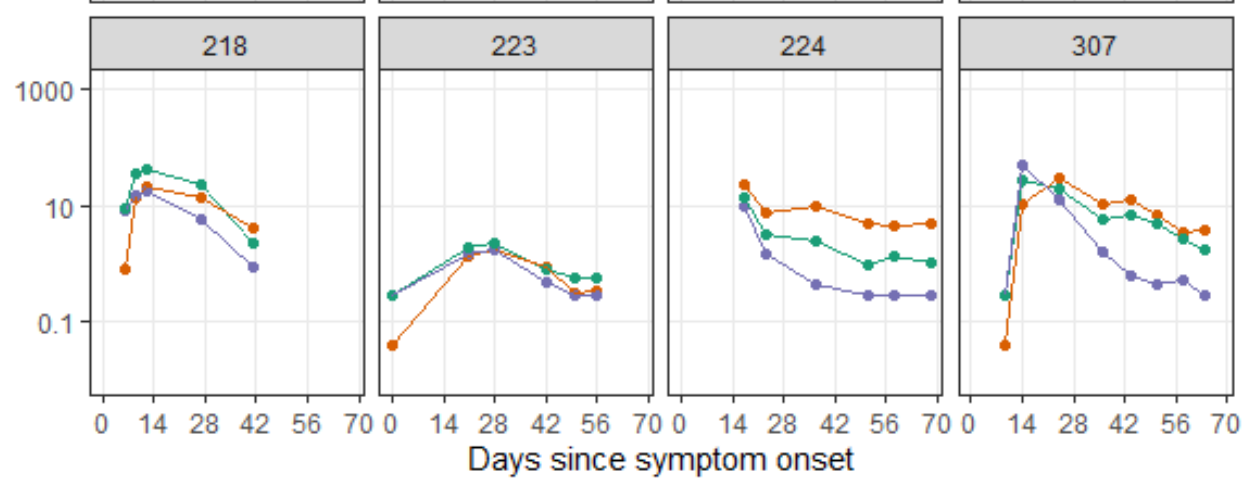

$\rightarrow \lg A$

$\rightarrow \lg G$

$\rightarrow \lg M$ 


\section{Table S1. Predictive accuracy of multiple isotypes for classifying controls and cases over time since symptom onset.}

Random forest models were used to calculate cvAUC. The isotype cut-offs chosen for calculating sensitivity were the maximum concentration $(\mu \mathrm{g} / \mathrm{mL}$ ) found among pre-pandemic controls (IgG: 0.57, $\operatorname{lgM}: 2.63$, IgA: 2.02). Samples with measurements above at least one cut-off were classified as cases.

\begin{tabular}{|c|c|c|c|}
\hline Isotypes & Days since symptom onset & cVAUC $(95 \% \mathrm{Cl})$ & Sensitivity (95\% Cl) \\
\hline \multirow[t]{4}{*}{$\lg A+\lg G$} & $\leq 7$ days & $0.64(0.54-0.75)$ & $0.12(0.09-0.15)$ \\
\hline & 8-14 days & $0.91(0.86-0.96)$ & $0.55(0.51-0.59)$ \\
\hline & $15-28$ days & $0.99(0.96-1.00)$ & $0.97(0.96-0.99)$ \\
\hline & $>28$ days & $1.00(1.00-1.00)$ & $0.97(0.96-0.99)$ \\
\hline \multirow[t]{4}{*}{$\lg M+\lg G$} & $\leq 7$ days & $0.64(0.54-0.74)$ & $0.10(0.08-0.13)$ \\
\hline & 8-14 days & $0.90(0.85-0.96)$ & $0.57(0.53-0.61)$ \\
\hline & $15-28$ days & $1.00(0.99-1.00)$ & $0.98(0.96-0.99)$ \\
\hline & $>28$ days & $0.98(0.95-1.00)$ & $0.97(0.96-0.99)$ \\
\hline \multirow[t]{4}{*}{$\lg M+\lg A$} & $\leq 7$ days & $0.61(0.51-0.71)$ & $0.11(0.08-0.14)$ \\
\hline & 8-14 days & $0.90(0.84-0.96)$ & $0.56(0.51-0.60)$ \\
\hline & $15-28$ days & $0.99(0.95-1.00)$ & $0.95(0.93-0.97)$ \\
\hline & $>28$ days & $0.98(0.94-1.00)$ & $0.69(0.64-0.73)$ \\
\hline \multirow[t]{4}{*}{$\lg M+\lg A+\lg G$} & $\leq 7$ days & $0.64(0.54-0.74)$ & $0.12(0.09-0.15)$ \\
\hline & 8-14 days & $0.92(0.86-0.97)$ & $0.60(0.56-0.64)$ \\
\hline & $15-28$ days & $1.00(0.99-1.00)$ & $0.98(0.96-0.99)$ \\
\hline & $>28$ days & $1.00(1.00-1.00)$ & $0.97(0.96-0.99)$ \\
\hline
\end{tabular}


Figure S4. Measurements of IgG, IgM, and IgA against SARSCoV-2 spike protein receptor binding domain among prepandemic controls and symptomatic PCR positive cases.

Black dashed line is at $0.57 \mu \mathrm{g} / \mathrm{mL}$ for $\operatorname{lgG}, 2.63 \mu \mathrm{g} / \mathrm{mL}$ for $\operatorname{lgM}$, and $2.02 \mu \mathrm{g} / \mathrm{mL}$ for $\operatorname{lgA}$.
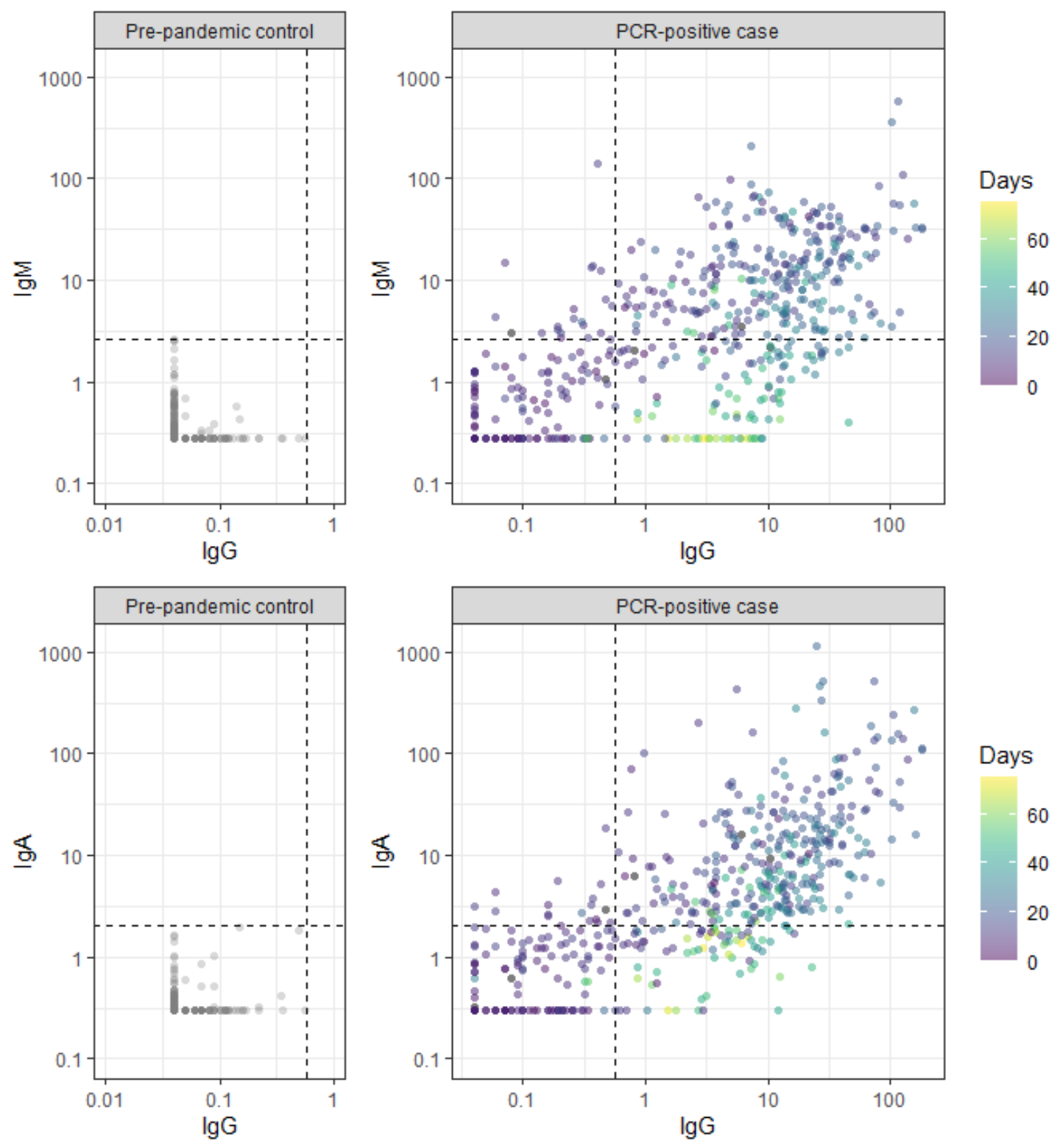
Figure S5. Receiver operating characteristic curve from random forest models and isotype contributions.

Each panel shows the ROC curves for cross-validated random forest models fit to serological measurements taken (A) under 7 days (cvAUC: 0.64), (B) 8-14 days (cvAUC: 0.92), (C) 15-28 days (cvAUC: 1.00) and over 28 days (cvAUC: 1.00 ) after symptom onset of PCR positive cases and pre-pandemic controls. Each blue line is one of ten cross-validated ROC curves for a specific time point. Median relative importance of each serological marker is shown in each bar graph.
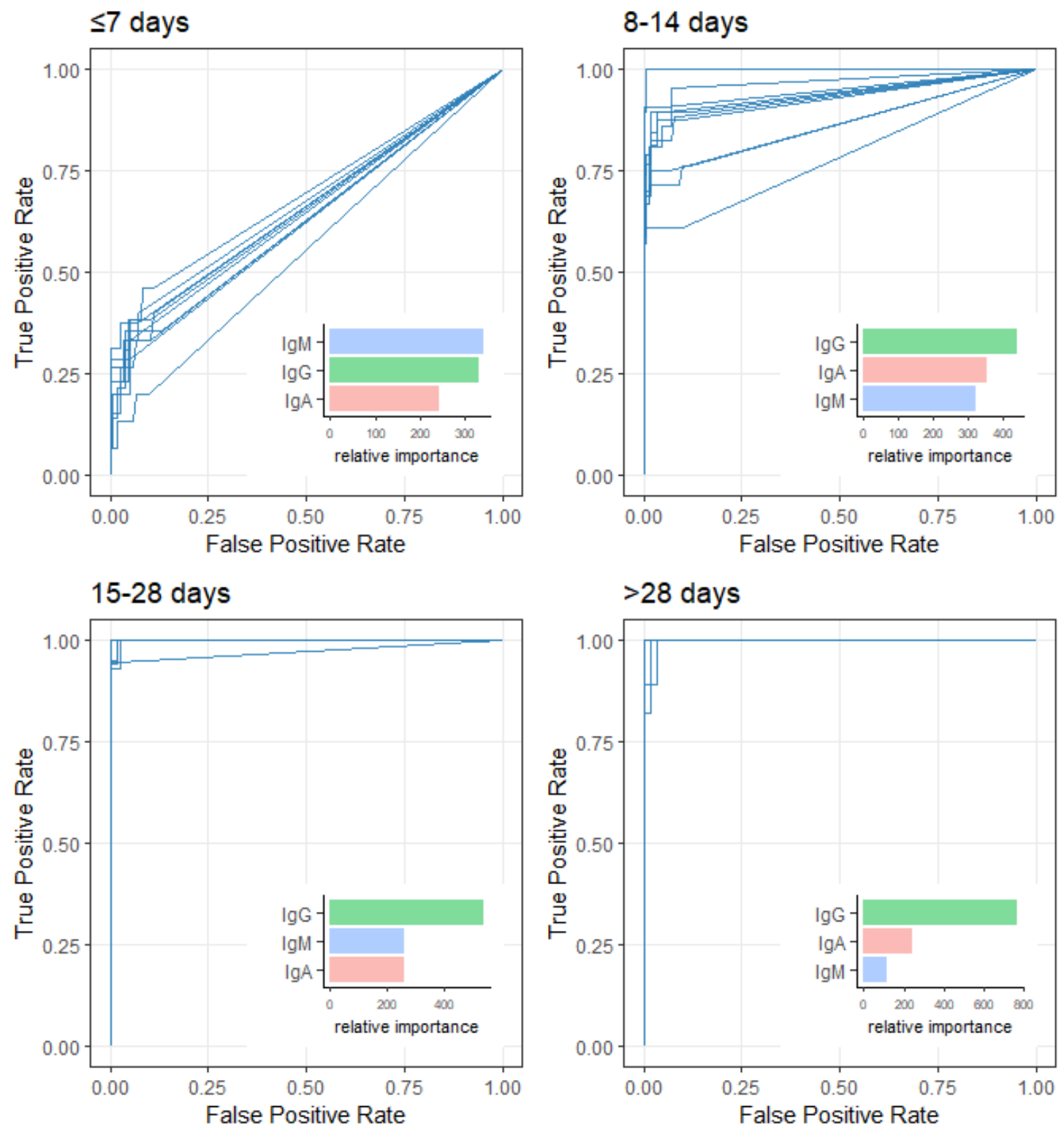


\section{Table S2. Parametric estimates of median time to seroconversion for each isotype by different patient characteristics.}

The isotype cut-offs chosen for seroconversion were the maximum concentration $(\mu \mathrm{g} / \mathrm{mL})$ found among pre-pandemic controls (IgG: 0.57, IgM: 2.63, IgA: 2.02). All models assumed that time to event followed a Weibull Distribution. Bootstrap 95\% confidence intervals are shown in parentheses. Not Hospitalized and Hospitalized, no ICU were combined due to small sample size.

\begin{tabular}{|c|c|c|c|}
\hline Isotype & Characteristic & $\begin{array}{l}\text { 50th percentile } \\
(95 \% \mathrm{Cl})\end{array}$ & $\begin{array}{l}\text { Difference } \\
(95 \% \mathrm{Cl})\end{array}$ \\
\hline \multirow[t]{10}{*}{$\lg A$} & Age & & \\
\hline & $<65$ years & $11.9(10.7-13.2)$ & \\
\hline & $\geq 65$ years & $13.3(10.2-17.3)$ & $1.4(-1.5-5.4)$ \\
\hline & Sex & & \\
\hline & Male & $11.8(10.6-13.1)$ & \\
\hline & Female & $11.5(9.3-14.1)$ & $-0.3(-2.6-2.4)$ \\
\hline & Severity & & \\
\hline & Not Hospitalized / Hospitalized, no ICU & $12.2(10.9-13.5)$ & \\
\hline & Hospitalized, required ICU & $9.3(7.2-11.9)$ & $-2.9(-5.0--0.4)$ \\
\hline & Died due to COVID-19 & $10.1(7.2-14.1)$ & $-2.1(-5.0-1.6)$ \\
\hline \multirow[t]{10}{*}{$\lg G$} & Age & & \\
\hline & $<65$ years & $10.9(10.0-11.9)$ & \\
\hline & $\geq 65$ years & $12.6(10.4-15.2)$ & $1.7(-0.3-4.0)$ \\
\hline & Sex & & \\
\hline & Male & $10.9(9.9-11.8)$ & \\
\hline & Female & $10.8(9.2-12.6)$ & $-0.1(-1.7-1.5)$ \\
\hline & Severity & & \\
\hline & Not Hospitalized / Hospitalized, no ICU & $11.3(10.3-12.3)$ & \\
\hline & Hospitalized, required ICU & $7.4(6.2-8.8)$ & $-3.8(-5.2--2.5)$ \\
\hline & Died due to COVID-19 & $11.6(8.4-15.8)$ & $0.4(-2.7-4.1)$ \\
\hline \multirow[t]{10}{*}{$\lg M$} & Age & & \\
\hline & $<65$ years & $12.1(10.8-13.7)$ & \\
\hline & $\geq 65$ years & $12.4(9.5-16.0)$ & $0.3(-2.6-3.8)$ \\
\hline & Sex & & \\
\hline & Male & $12.2(10.9-13.8)$ & \\
\hline & Female & $16.0(11.4-22.5)$ & $3.8(-0.5-9.9)$ \\
\hline & Severity & & \\
\hline & Not Hospitalized / Hospitalized, no ICU & $12.3(10.8-14.0)$ & \\
\hline & Hospitalized, required ICU & $10.1(7.4-13.7)$ & $-2.2(-4.8-1.1)$ \\
\hline & Died due to COVID-19 & $9.9(6.4-14.4)$ & $-2.5(-5.9-2.0)$ \\
\hline
\end{tabular}


Figure S6. Measurements of $\lg G$, IgA, and IgM against the RBD of other coronaviruses among pre-pandemic controls and PCR positive cases.

Each dot represents a unique measurement of a serological marker (Row A: IgG, Row B: IgA, Row C: IgM) in pre-pandemic controls (left panels) and PCR positive cases (right panels) for each coronavirus. Each line connects measurements (dots) for individuals.

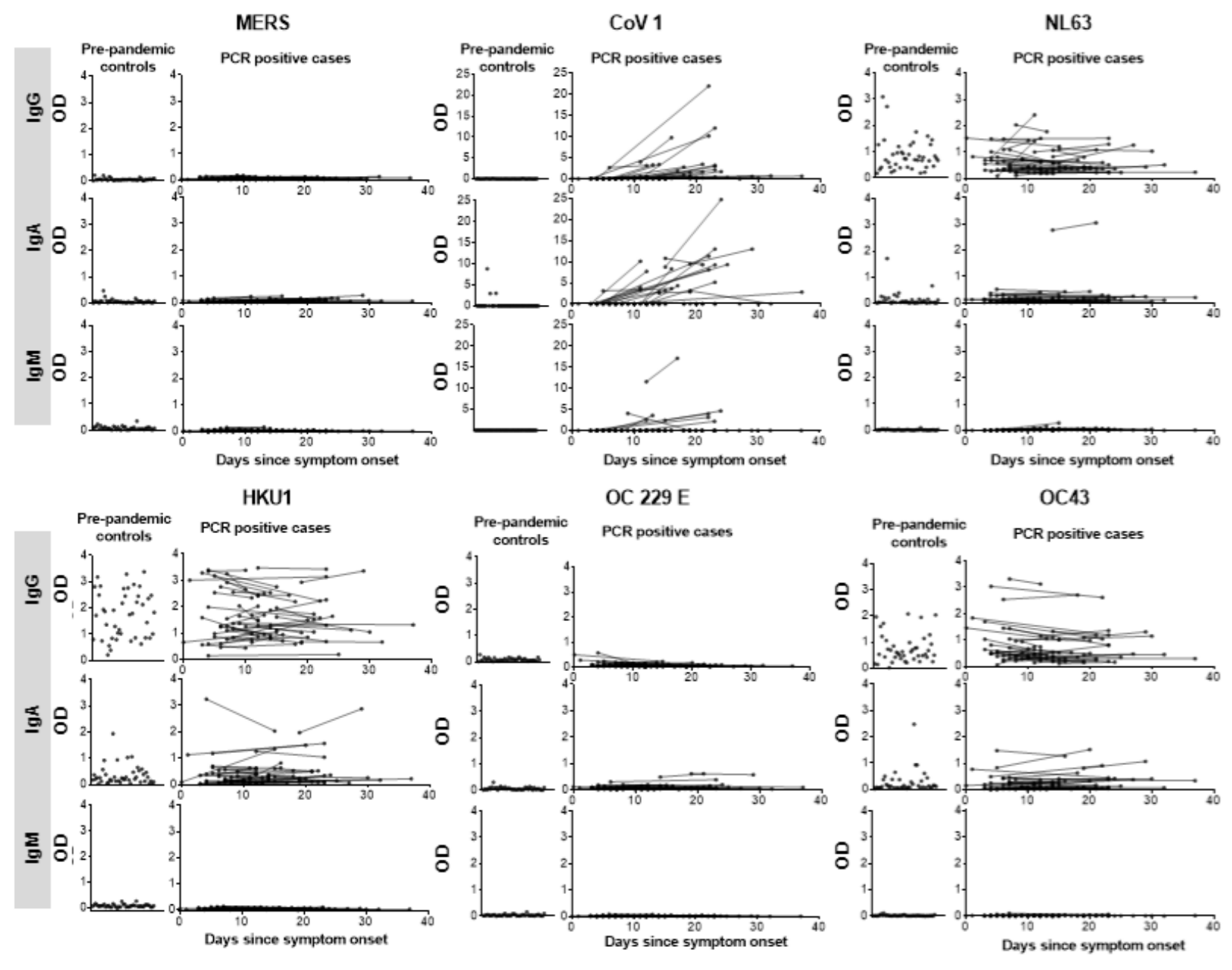


medRxiv preprint doi: https://doi.org/10.1101/2020.07.18.20155374; this version posted July 20, 2020. The copyright holder for this preprint (which was not certified by peer review) is the author/funder, who has granted medRxiv a license to display the preprint in perpetuity.

It is made available under a CC-BY 4.0 International license .

\section{Figure S7. Correlation between plasma and dried blood spot measurements (DBS).}

Plot of anti-RBD antibody IgG measurement in plasma versus DBS of 20 COVID cases (at 2 timepoints) and 20 pre-pandemic controls. The Pearson correlation coefficient ( $r$ ) is shown. The dotted gray lines represent the concentration cut-off for seropositivity with plasma.

\section{$\lg \mathbf{G}$}

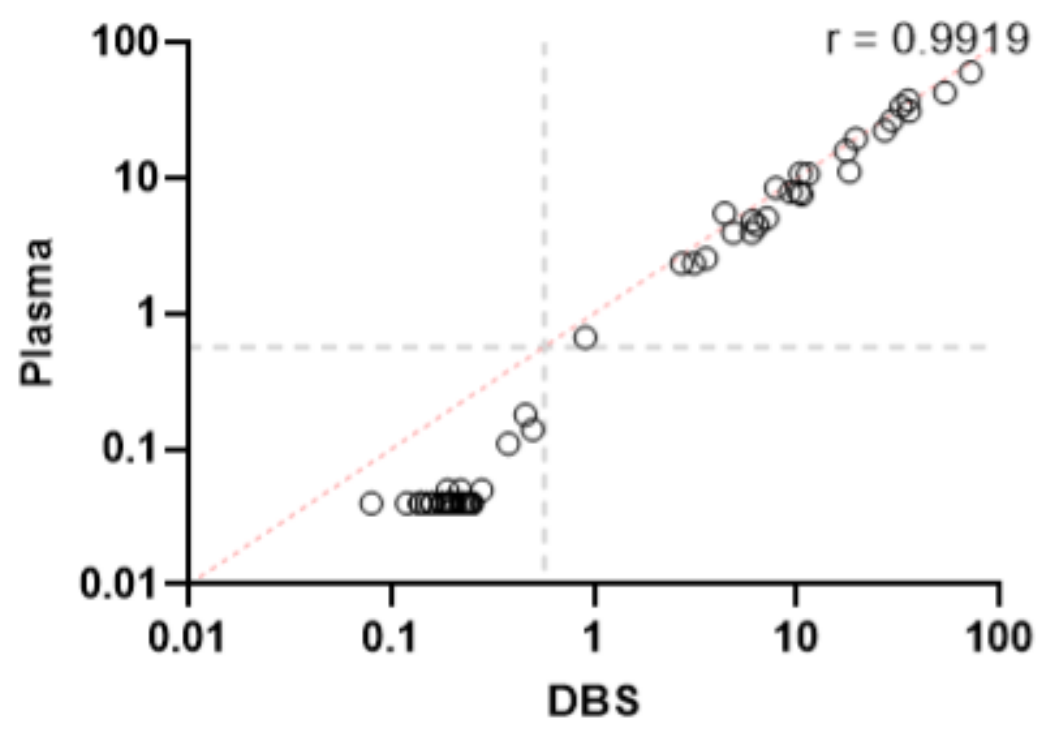

